\title{
Artwork
}

\section{Sealskin Flower by the Water}

\section{Angelina Heer ${ }^{1}$}

1University of New Brunswick

DOI: https://doi.org/10.15273/hpj.v1i2.11195


My name is Angelina Heer and I am a member of Sucker Creek First Nation. I am living and working as a guest on the unceded and unsurrendered traditional lands of the Wolastoqiyik and Mi'kmaq People. I am also a graduate student in the MEd Counselling Program at the University of New Brunswick. My thesis is focused towards a wholistic perspective on the journey of healing for Indigenous men reintegrating back into community after incarceration. The Atlantic Indigenous Mentorship Network (IMN) has become an important part of my journey as graduate student. The IMN provides a safe space to navigate the journey of Indigenous research in academia. I made this seal skin broach in a workshop offered by IMN. Working on my thesis has inspired me to reconnect with my creative side which got lost in the busyness of life. 